\title{
A Right of Access to Medical Records: The Contemporary Case Law of the European Court of Human Rights and the Jurisprudence of Germany
}

\author{
By Anatoliy A. Lytvynenko*
}

The right of access to medical records is a secondary contractual right originating from the patient's right to self-determination, and is exercised prior to commencing a malpractice action, or, in less commonly, for private discovery. This right is countered by the physician's obligation to medical secrecy as well as therapeutic concerns, mainly in order not to harm the patient's physical and mental condition, a qualification which is frequently applied in psychiatric cases. The jurisprudence of the Commonwealth countries and Continental Europe is quite versatile and controversial. The subject has also launched several actions adjudicated by the European Court of Human Rights. The latter court, however, still lacks a thorough and comprehensive jurisprudence on the right of access to medical records, though it is quite clear that such actions will have to be addressed more frequently by the ECHR in the near future. For these reasons, the European Court of Human Rights urgently requires a number of general rules upon which these lawsuits may be decided. Therefore, the author of the paper intends to analyse the jurisprudence of the Republic of Germany in order to align and specify general rules concerning access to medical records and the restrictions of exercising this right. The choice of German jurisprudence is dictated by the fact that German courts have developed a firm body of case law regarding access to medical records, encompassing diverse judgments with complicated and outstanding circumstances, which may be useful for the courts in Continental Europe as well as the European Court of Human Rights.

Keywords: data privacy; right to self-determination; medical confidentiality; medical malpractice; European Court of Human Rights; German medical law.

\section{Introduction}

In German jurisprudence, the patient's right to access their medical records derives from the patient's right to self-determination and dignity, which presupposes that a patient may not be regarded as a mere object of treatment with no actual rights. ${ }^{1}$ This right includes access to diverse types of medical records,

* PhD (Law) Student, Ivan Franko National University of Lviv, Ukraine; PhD (Law) Student, Robert Gordon University of Aberdeen, Scotland, UK. E-mail: anat.lytvynenko@gmail.com.

${ }^{1}$ See $B G H, 23.11 .1982$; VI ZR 222/79, para. 16. 
such as those describing their current state of health and prognosis for the future. ${ }^{2}$ There are many types of medical records ${ }^{3}$ minor medical records may be very accessible, ${ }^{4}$ while others, such as psychiatric records, may have limited accessibility. ${ }^{5}$ Most often, the medical records are accessed prior to the commencement of a malpractice action against a hospital or a physician(s), which is frequent for common law jurisdictions, such as England ${ }^{6}$ or the United States. In Germany, the patient has no actual obligation to demonstrate a legal interest in obtaining health records in conventional cases ${ }^{8}$ (though in some earlier cases they were requested as proof). ${ }^{9}$ The German case law repeatedly affirmed that a patient's right to access his medical records is a "case law-bred" right deriving from the contract of treatment between patient and physician or hospital, ${ }^{10}$ whereas in some civil law jurisdictions, such as France, patients have a statutory right to access their medical records based upon Civil Code provisions. ${ }^{11}$ In the early stages of the jurisprudence on the subject, both $\mathrm{US}^{12}$ and German ${ }^{13}$ commentators concluded there must be a common law-originating right to access to medical records. The further development of patient's rights with respect to privacy was also reflected in the international human rights courts.

The timeline of the subject depends on jurisprudence both in "common law" and "civil law". For instance, the right to access medical records in England resulted from a 1970 act, which allowed records to be produced as documentary evidence for trial. Prior to this, according to the English courts, medical records were produced only upon a subpoena. ${ }^{14}$ The 1970 s jurisprudence of England allowed very restricted access to records and did not grant it to the plaintiff himself, limiting it only to legal and medical advisors: ${ }^{15}$ in the $1970 \mathrm{~s}$, the courts followed the hospital record-keeping practices which held that patients should not be allowed to examine their medical data, as it may be detrimental for them, the prognosis may be depressing, they may be unable to comprehend the information properly and, finally, that physicians might avoid putting important information in

${ }^{2}$ OLG Bremen, 31.07.1979 - 1 U 47/79, para. 15 In Re D (Infants), [1970] 1 W.L.R. 599, 600-603.; $D$ v. NSPCC, [1978] A.C. 171 at. $242-246$.

${ }^{3}$ Wischmach (1998) at 241-242.

${ }^{4}$ See e.g. $B G H, 23.11 .1982$ - VI ZR 222/79, para. 17-30.

${ }^{5}$ See e.g. $B G H, 06.12 .1988$ - VI ZR 76/88, para. 7, 9.

${ }^{6}$ See Dunning v United Liverpool Hospitals' Board of Governors, [1973] 1 W.L.R. 586; Deistung v South West Metropolitan Regional Hospital Board, [1974] 1 W.L.R. 213; Davidson v Lloyd Aircraft Services Ltd., [1974] 1 W.L.R. 1042; McIvor v Southern Health \& Social Service Board, [1978] 1 W.L.R. 757; Gaskin v. United Kindgom (1989) 12 EHRR 36, and Church of Scientology v DHSS, [1979] 1 W.L.R. 723.

${ }^{7}$ Cannell. Medical and Surgical Clinic, 315 N.E.2d 278, 280 (1974).

${ }^{8} B G H, 31.05 .1983$ - VI ZR 259/81, para. 7-8; BGH, 02.10.1984 - VI ZR 311/82, p. 5.

${ }^{9}$ OLG Koln, 12.11.1981, 7U 96/81, para. 18.

${ }^{10}$ See $B G H, 23.11 .1982$; VI ZR 222/79, para. 15 .

${ }^{11}$ See Demont (2000) at 76-79.

${ }^{12}$ See Harpst (1962) at 273-275; Dworkin (1979) at 90-91; Feenan (1996) at 101-102, 105-106.

${ }^{13}$ See Deutsch (1992) at 179-171.

${ }^{14}$ Davidson v Lloyd Aircraft Services Ltd., [1974] 1 W.L.R. 1042, 1045.

${ }^{15}$ See e.g. Dunning $v$ United Liverpool Hospitals' Board of Governors, [1973] 1 W.L.R. 586, 590; Deistung v South West Metropolitan Regional Hospital Board, [1974] 1 W.L.R. 213, 216-217. 
writing for fear that the patient might gain access to the records. ${ }^{16}$ Though the McIvor judgment rejected most of these restrictions, especially that which allowed withholding the records from the plaintiffs themselves, ${ }^{17}$ English courts allowed hospitals to use their discretion while deciding whether there is public interest in withholding the records, and the restrictions concerning "deplorability" remained (thus provoking the Gaskin trial at the European Court of Human Rights) ${ }^{18}$ as well as denying access to avoid abuse of process. ${ }^{19}$

The English courts also held that childcare reports involving medical records are strictly confidential and "public interest" makes their disclosure impermissible. ${ }^{20}$ The Scottish case law is a bit younger than its English counterpart and strictly adheres to considerations of the applicant's legal interests. ${ }^{21}$ The US jurisprudence dates back to the forties and the earlier cases were entirely connected to malpractice suits. ${ }^{22}$ Some American courts recognised furnishing medical records as a common law duty of the physician or hospital, ${ }^{23}$ or a statutory one. ${ }^{24}$ In fact, the German courts also upheld the notion that access to records is a case laworiginating right. ${ }^{25}$ In spite of the fact that German courts faced suits regarding granting access to medical records in the 1970s, the right to inspect the records, as an expansion of the right to autonomy or self-determination, was recognised by the German Federal Constitutional Court only in $1998 .{ }^{26}$ In Austria, the right to access medical records was recognised by the Supreme Court in $1984 .{ }^{27}$ Some common law jurisdictions hadn't been required to address similar suits prior to the last few decades; for instance, the Australian High Court found there was no common law right granting access to one's health records. ${ }^{28}$

\section{The Existing Jurisprudence of the European Court of Human Rights}

In the last three decades, the European Court of Human Rights has repeatedly faced suits involving data privacy, as well as a number of actions involving the right to self-determination. All of the given lawsuits were cognizant under Art. 8 of the ECHR, though data privacy is only one of the constituents that form the body of jurisprudence settled upon in the aforementioned provision. In some

\footnotetext{
${ }^{16}$ Davidson v Lloyd Aircraft Services Ltd., [1974] 1 W.L.R. 1042, 1045-1046.

${ }^{17}$ McIvor v Southern Health \& Social Service Board, [1978] 1 W.L.R. 757, 760-761.

${ }^{18}$ Gaskin v United Kindgom (1989) 12 EHRR 36.

${ }^{19}$ Church of Scientology v DHSS, [1979] 1 W.L.R. 723, 728 and seq.

${ }^{20}$ See e.g. In Re D (Infants) [1970] 1 W.L.R. 599, 600-603.; D v NSPCC, [1978] A.C. 171, 242-246.

${ }^{21}$ Boyle v Glasgow Royal Infirmary and Associated Hospitals, 1969 SC 72; 1969 S.L.T. 137.

${ }^{22}$ Hoyt v. Cornwall Hospital, 169 Misc. 361, 363 (N.Y. 1940); In re Weiss, 147 N.Y.S 2d. 455, 456 (1955).

${ }^{23}$ See Cannell v. Medical \& Surgical Clinic S.C., 315 N.E.2d 278, 280 (1974); Rabens v. Jackson Park Hospital Foundation, 40 Ill.App.3d 113, 116; 351 N.E.2d 276, 279 (1976).

${ }^{24}$ Clay v. Little Co. of Mary Hospital, 277 Ill.App.3d 175, 178-180; 213 Ill.Dec. 866, 868-869; 660 N.E.2d 123, 125-126 (1995).

${ }^{25} B G H, 31.05 .1983$ - VI ZR 259/81, para. 12.

${ }^{26}$ BVerfG, 16.09.1998 - 1 BvR 1130/98, para. 9-11.

${ }^{27}$ See $O G H 23.5 .1984,1$ Ob 550/84

${ }^{28}$ Breen v Williams, [1996] H.C. 78,
} 
recent cases, a breach of Art. 10 of the ECHR (in the sense of "receiving" information) was also alleged in conjunction with a refusal to release governmental records (though not strictly hospital records, as in the European Court's trials or German cases which will be discussed in the next sections). ${ }^{29}$ Some other trials have involved the retention of records concerning employment, military service, political party membership and trade union involvement; ${ }^{30}$ an attempt to receive an order to disclose one's data from intelligence service archives, ${ }^{31}$ a number of trials concerning health records (which we will briefly discuss in the following chapter) ${ }^{32}$ the retention of personal data in intelligence service archives ${ }^{33}$ or police archives, ${ }^{34}$ as well as banking confidentiality ${ }^{35}$ and the retention of medical records. ${ }^{36}$

The leading case on this subject is the Gaskin trial. The initial suit was brought in 1980, when the plaintiff, a young man possessing a "bad record", was unable to find himself an appropriate job. For years, the plaintiff had grown up in several foster homes, orphanages and infirmaries, until he came of age. Now, he blamed the defendant (the Liverpool City Council) for negligent care, as throughout the years he had suffered from various health problems, including psychiatric issues. In order to substantiate his case, he applied to the city council to gain access to his old medical records, which he intended to share with his advisors. However, the English court concluded that childcare reports may not be revealed, as there is substantial public interest in preserving them in full confidentiality, ${ }^{37}$ and cited in its decision a number of older lawsuits involving access to childcare reports. ${ }^{38}$ The European Court, after having assessed the key facts of the case, affirmed cognizance of the action under Art. 8 of the Convention, finding that the right of access to health records falls within the scope of the aforesaid provision. The European Court decided for the plaintiff, finding that he had a well-established legal interest in his health records, as this issue apparently belonged to "the right to private and family life." In addition, he didn't have an independent judicial body to appeal to. ${ }^{39}$ A similar suit appeared before the court

\footnotetext{
${ }^{29}$ Roche v United Kingdom [2005] ECHR 956, para. 170-172. In this case, the plaintiff desired to obtain records confirming he had been injured while being on military service in the 1950s, in order to enable him to receive a "service" pension. These were no hospital records, as I mentioned before, but only governmental records, though medical-related. Though the plaintiff didn't prevail in action upon Art. 10, he managed to recover on the basis of a violation of his right to privacy. It should be also noted that multi-claim lawsuits are quite frequent in the European Court. For instance, in Leander, the plaintiff invoked not only an Art. 8 and 10 breach, but Art. 14 (a right to an effective domestic remedy) as well. However, he didn't prevail on any of the counts.

${ }^{30}$ Leander $v$ Sweden [1987] 9 EHRR 433.

${ }^{31}$ Szulc v Poland, [2013] 57 EHRR 5, 163-167 (the trial facts are stated on the pages cited herein).

${ }^{32}$ See e.g., Odievre v France, [2003] F.C.R. 621.

${ }^{33}$ See Rotaru v Romania, [2000] ECHR 92, para. 43.

${ }^{34}$ See Khehili v Switzerland, [2011] ECHR 195, para. 15 etc. (reported under the name Affaire Khelili c Suisse in French).

${ }^{35}$ B.F.B. Villa-Nova v Portugal, [2015] ECHR 1049; GSB v Switzerland, [2015] ECHR 1122, para. 75-98.

${ }^{36} S$ \& Marper v United Kindgom, [2008] ECHR 1581.

${ }^{37}$ Gaskin v Liverpool City Council, [1980] 1 W.L.R. 1549, 1552-1553 [per Denning, L.J]

${ }^{38}$ See In Re D (Infants), [1970] 1 W.L.R. 599, 600-602 etc.; D v NSPCC, [1978] A.C. 171, 242-246.

${ }^{39}$ Gaskin v United Kindgom (1989) 12 EHRR 36.
} 
in the mid-1990s, MG v. United Kingdom. The facts were basically similar to the Gaskin trial: the plaintiff had grown up in a number of orphanages. As an adult, he attempted to obtain access to his childcare reports, in order to reconstruct his memories concerning his early years (mid-1960s to early 1970s), and especially facts regarding violent abuse by his (now deceased) father. He also planned to sue the municipal authorities in case the medical records displayed any malpractice by the municipal bodies regarding his custody. Though upon his earlier requests he managed to obtain insight to a number of documents, those did not relate to most of his adolescent years, which were seemingly concealed and not entrusted to him. The verdict was the same: the European Court found that plaintiff had a vital interest in his medical records, and again, no independent judicial body to appeal to, stating that he prevailed in action under Art. 8 of the Convention. ${ }^{40}$

Another interesting lawsuit was Odievre $v$. France, an example of a sophisticated action concerning the wish to gain access to adoption records in order to reveal the identity of the biological parent. These trials are quite complex, as adoption records possess a high degree of confidentiality, meaning the plaintiff has little chance to prevail in court. For instance, American scholars in the 1970s were confident that it was the United States' state policy to keep such records sealed $^{41}$ (and thus referred to as "sealed records"). This policy was rarely overturned, and only on occasions when the plaintiff proved that the revelation was necessary for property inheritance, ${ }^{42}$ or implied some medical reasons to access the sealed records. ${ }^{43}$ The US jurisprudence also faced tort actions for the wrongful disclosure of adoption records concerning a biological mother. ${ }^{44}$ The German legislature asserted a prohibition on revealing adoption files, though not unqualified: these records may be disclosed if a strong justifiable interest is shown, and if all parties (e.g. biological sisters, brothers etc.) gave consent to the disclosure. ${ }^{45}$ This approach arose from a French civil law concept of the "l'accouchement secret", or "Accouchement sous X", upon which the records of biological parents are supposed to be eternally confidential. The legal framework of the concept is mostly based upon a 1904 law. ${ }^{46}$ The French jurisprudence of the $19^{\text {th }}$ century recognised birth records to be highly confidential and even physicians found reporting personal data outside the scope of civil code demands to be a breach of confidence (even in cases reported to public bodies, but not to any third parties). ${ }^{47}$

\footnotetext{
${ }^{40} M G v$ United Kindgom, App. 39393/98, judgment of 29 Sept. 2002,

${ }^{41}$ Crane (1986) at 647.

${ }^{42}$ Massey v. Parker, 369 So. 2d 1310, 1313-1315 (La. 1979).

${ }^{43}$ Kirsch v. Parker, 383 So. 2d 384, 387-388 (La. 1980).

${ }^{44}$ See Humphers v. First Intestate Bank, 298 Or. 706; 696 P. 527, 533-536 (Or. 1985).

${ }^{45}$ OLG Bayern, 07.02.1996 - 1 Z BR 72/95, para. 9-11.

${ }^{46}$ Bulletin officiel du Ministère de l'intérieur (1904) at 282-283. Concerning the French legislature's initiatives on "l'accouchement secret" and their application, see Passion (1983) at 478 et seq.

${ }^{47}$ See e.g. Mallet, 16 Sept. 1843, Cour de cass.; Ch. Crim., Sirey 1843 I 915, at p. 916; 918-919. In this trial, a physician from La Rochelle reported the birth records of a newly-born child to a town's registrar. As he was at the confinement, he was obliged to report it under the law within 3 days (Art. 56 Cod. Civ.; Sirey 1844 I 669, 671-672). He refused to reveal the mother's name for unspecified reasons, with a reference to medical secrecy. He was prosecuted, but won the appeal. The court of cassation affirmed the lower court's judgment, stating he was not obliged to report more than the
} 
As the legal concept progressed, being codified in the Civil Code, it received a more elaborate legal regulation. The Odievre trial resulted from this concept. The plaintiff, a French national born in 1965, was abandoned by her parents at birth. In the late 1960s, she was adopted and carried another surname (under which she sued) thereafter. While in her 30s, the plaintiff applied to a local child welfare service located in Seine to obtain the information concerning her biological parents. The plaintiff also believed she had siblings. But the only document she managed to receive were anonymised records, which were apparently valueless to her. As the appeals were unsuccessful, she lodged a suit to the European Court of Human Rights. The court, having recognised cognizance over the case, held that though it was not very typical to have legislation and case law allowing anonymous childbirth in much of Europe, ${ }^{48}$ this was not true for France, which had a long legal tradition of recognizing anonymous births. Furthermore, existing French legislation and jurisprudence allowed access to depersonalizsed records, meaning the plaintiff was not (in the stringent sense of the word) deprived of her informational rights. Thus, the court affirmed the French ruling. ${ }^{49}$ The ruling of Godelli v. Italy, with nearly identical facts, was somewhat reversed. The plaintiff, an elderly woman, decided to discover her origins. She was born in 1943 and adopted at the age of 6 . In her youth, she discovered that a girl from her village was also adopted, but the adoptive parents of both repeatedly suppressed any contacts between them and never disclosed the true identity of her parents. At age 63 (in 2006), the plaintiff applied to the town register to receive her birth records, but her request was denied. Her lawsuits at the trial and appellate courts were unsuccessful. ${ }^{50}$ The court found that the Italian civil law provisions on the subject granted access only in two cases: 1) a qualified one - to the physician; 2) upon a court order, if the plaintiff is over 25 , and there are medical reasons for the disclosure. The court found that though anonymised childbirth is quite rare in Continental law jurisdictions, it is not as rare as would be expected. ${ }^{51}$ At trial before the European Court, the woman claimed that she had been unable to receive non-identifying data, putting the count upon Art. 8.1 of the Convention. The court, assessing the balance, stated that privacy rights are expected to be balanced between two competing private interests - those of the person given up for adoption, and those of the birth parents. In Odievre v. France, the plaintiff easily received depersonalised birth records, of which she had been deprived in the instant case. ${ }^{52}$ The court, attempting to be as fair as possible, stated that the plaintiff, being nearly 70 years of age (at the time of the trial) had attempted to trace her origins, a desire that doesn't vanish with age. Italian law, unlike its French counterpart, did not provide an adequate balance by lodging a possibility to

infant's personal data. Despite the fact that in earlier times lower French courts interpreted it differently, this approach was accepted and applied in succeeding trials with identical circumstances, Romieux c. Min. Publ, 1 Juin 1844, Cour de cass; Ch. Crim., Sirey 1844 I 669, 672.

${ }^{48}$ See also Godelli v Italy, [2012] ECHR 347, para. 28-31.

${ }^{49}$ Odievre . France, [2003] F.C.R. 621, para. 15-onw.

${ }^{50}$ Godelli v Italy, [2012] EC.HR 347, para. 7-15 (statement of facts).

${ }^{51}$ Godelli v Italy, [2012] ECHR 374, para. 18-23; 28-31 (concerning the analysis of Italian civil law and jurisprudence).

${ }^{52}$ Odievre v France, [2003] F.C.R. 621, para. 12. 
inspect anonymised childbirth records. Therefore, the court found in favour of the plaintiff, stating that her right to privacy had been violated. ${ }^{53}$

Although the European Court of Human Rights possesses some jurisprudence on the subject of access to medical records, the existing case law is far from enough to be able to elaborate general rules on the right to access and its exemptions. By means of analysing various Commonwealth and Continental Europe jurisprudence, this may be substantially enhanced. In one of my recent papers, ${ }^{54}$ I demonstrated the trends in the United Kingdom and American jurisprudence on the subject from the perspective of the Anglo-American law.

\section{General Assumptions Regarding Access to Health Records in German Jurisprudence}

The right of access to medical records is a contractual right and subsequently derives from the contract between the patient and physician. ${ }^{55}$ This is also the position of the Austrian courts. ${ }^{56}$ According to some courts, the right of access to medical records derives from the patient's right not only to a diagnosis and therapy, but to information concerning their medical records, which may be related to their current state of health and future prognosis. ${ }^{57}$ This is in addition to the right to autonomy, or self-determination, which, apart from informed consent ${ }^{58}$ (including, in more recent jurisprudence, a consent to transferring medical data from one medical institution to another), ${ }^{59}$ involves an informational right of access to medical records. ${ }^{60}$ According to applicable German case law, special provisions concerning the patient's right to access are not required, making it practically a "common-law" right. ${ }^{61}$ In fact, in the late 1970s, a Limburg regional court expressed a dictum upon which there may be a contractual provision restricting access to medical records in some "exceptional" circumstances (though

\footnotetext{
${ }^{53}$ Godelli v Italy, [2012] EC.HR 374, para. 50; 54-56; 57-59.

${ }^{54}$ See Lytvynenko (2019a).

${ }^{55}$ See the following decisions: $A G$ Weltzar, 15.08.1978 - 3C 707/78, para. 8-9 and 15; LG Gottingen, 16.11.1978 - 2 O 152/78, para. 9-10; 16; BGH, 23.11.1982; VI ZR 222/79, para. 15; BGH, 31.05.1983 - VI ZR 259/81, para. 9; OLG Munchen, 19.04.2001 - 1 U 6107/00, para. 21.

${ }^{56}$ OGH 23.05.1984, 1 Ob. 550/84.

${ }^{57}$ OLG Bremen, 31.07.1979 - $1 \mathrm{U} 47 / 49$, para. 15.

${ }^{58}$ See, for instance, $B G H, 16.01 .1959$, VI ZR 179/57, para. 14-16, etc. There, the plaintiff was not informed of the potential hazards of radiotherapy treatment. The case was won on the basis of breach of contract/breach of duty to inform. This leading case raised the concept of "selfdetermination" ("Recht der Selbstbestimmung") in German jurisprudence (see para. 15 of the judgment in particular). The 1950s (or earlier) case law acknowledged a duty to inform the patient only of frequent side effects, see $B G H, 11.04 .1956$ - VI ZR 20/55, para. 10-12. However, in cases where negligence was proved, the plaintiff was able to win a malpractice suit on this basis.

${ }^{59}$ See AG Neunkirchen, 28.10.1991, 5 C 648/91, para. 12-onw. Concerning the right to autonomy see para. 16. There the court held that the transfer of an elderly patient's medical data from a hospital to a clearinghouse without written consent is void.

${ }^{60}$ OLG Bremen, 31.07.1979 - $1 \mathrm{U}$ 47/79, para. 15.

${ }^{61} B G H, 31.05 .1983$ - VI ZR 259/81, para. 12.
} 
not specified in the judgment) or there may be a special contract between the patient and physician or hospital concerning such restrictions. ${ }^{62}$

In comparison to commonwealth states, such as Scotland, ${ }^{63}$ the patient conventionally does not need to display any legal interest in obtaining access to medical records. ${ }^{64}$ In certain civil actions involving confidential medical records, such as psychiatric data, or rights of heirs to access the deceased person's health data, ${ }^{65}$ the court may request that the plaintiff justify their request to access the medical records. ${ }^{66}$ In some earlier judgments, the German courts held that a plaintiff was allowed access to medical records in cases in which they had a substantial legal interest, most often when preparing a medical malpractice suit. ${ }^{67}$ In the early 1980s, the Supreme Court announced a variety of cases in which access to medical records may be limited, ${ }^{68}$ or restrictions imposed upon very sensitive personal information. ${ }^{69}$ Similarly, the court ruled that, as in England ${ }^{70}$, the USA ${ }^{71}$ and Canada, ${ }^{72}$ the physician or a hospital is the owner of their patients' medical records, but their property rights are limited and qualified to the patient's right to access them; ${ }^{73}$ The property rights may not serve as an excuse not to produce medical records upon request. In a 2001 OLG Munich decision, for instance, after having suffered a brain injury and being unsuccessfully treated, the plaintiff applied to the hospital to obtain photocopies of their MRI, computerised tomography and other records, promising to return them in 6 months. The defendant refused, inter alia, claiming that the production of these documents may adversely affect the hospital's property rights, and offered photocopies of the material instead. The court determined that this solution did not comply with the defendant's contractual obligation to supply the records, and held they such records are quite frequently disposed at trial and damage to them is rare. In this

\footnotetext{
${ }^{62}$ LG Limburg, 17.01.1979 - 3 S 244/78, para. 13.

${ }^{63}$ See generally, Boyle v Glasgow Royal Infirmary and Associated Hospitals, 1969 S.C. 72; 1969 S.L.T. 137.

${ }^{64} B G H, 31.05 .1983$ - VI ZR 259/81, para. 8; BGH, 02.10.1984 - VI ZR 311/82; at p. 5.

${ }^{65} B G H, 31.05 .1983$ - VI ZR 259/81, para. 19-20.

${ }^{66}$ See e.g. LG Saarbrucken, 20.09.1995 - 16 S 1/93, para. 7.

${ }^{67}$ OLG Köln, 12.11.1981: 7 U 96/81, para. 18.

${ }^{68} B G H, 23.11 .1982$; VI ZR 222/79, para. 17-et seq.

${ }^{69} \mathrm{BGH}, 06.12 .1988$ - VI ZR 76/88, para. 7.

${ }^{70}$ R. v Mid Glamorgan Family Health Services Authority \& Another/Ex Parte Martin, [1995] 1 W.L.R. 110, 116; 119-120.

${ }^{71}$ In Re June 1979 Allegheny County Grand Jury Investigation, 415 A.2d 73, 76-77 (1979).

${ }^{72}$ This issue in Canada is quite complicated. The leading opinion of McInerney v Macdonald, [1992] 2 S.C.R. 138, where a patient merely requested to examine an entire medical file and was refused, didn't display a firm application of property rights, as the Supreme Court based its decision upon the fiduciary duty of a physician (see p. 150-152). At the same time, there are some decisions of lower Canadian courts where the hospitals or doctor's property rights in medical records were firmly recognised, see Lamothe v. Mokleby \& Erle Holdings Co., 106 D.L.R. (3d) 233 (1979), para. 8-9; Re Mitchel \& St. Michael's Hospital, 112 D.L.R. (3d) 360 (1980), para. 10-11. The former case, however, dealt with the proprietary status of medical records in terms of their purchasing alongside with other property.

${ }^{73} B G H, 23.11 .1982$; VI ZR 222/79, para. 16.
} 
matter, the property status of the records was not actually addressed, and the plaintiff's counsel guaranteed their safety, thus the appeal was dismissed. ${ }^{74}$

It is possible that the denial of access to medical records by the physician or hospital may be justified and substantial opposing interest may be displayed at trial. ${ }^{75}$ Even in cases where the patient requests highly-confidential medical records (most often those relating to psychiatric treatment), ${ }^{76}$ a decision to allow only limited access, deemed by the court under the label of "therapeutic reasons", ${ }^{77}$ must be justified by defendant hospitals by precise facts (e.g. worsening of a patient's condition in the last few years, which may become further aggravated if the records are not concealed and handed over to plaintiff). ${ }^{78}$ The limited access may be justified based on an evaluation of their potential influence on the plaintiff's disease and their current health condition. ${ }^{79}$ People who are detained in psychiatric facilities cannot be deprived of their right to inspect medical records, and in psychiatric cases, an exact and sufficient risk of an illness reoccurring may justify the restriction. ${ }^{80}$ More recent case law grants a right of access to medical records not only to people who are detained in psychiatric facilities, but to prisoners serving their sentence as well; however, there may be additional procedures to implementing this right, taking into account the fact these people are in isolated institutions, as a mental facility, a reformatory or a prison. ${ }^{81}$ In some psychiatric cases, the records may be disclosed to the plaintiff in the presence of his medical advisor or a consulting physician, especially if there are grounds to believe that the information contained in the records may adversely affect the plaintiff's mental condition $^{82}$.

The patient being treated at the hospital where all their records are maintained, has a qualified property right to them Upon their death, this right might be transferred to their heirs unless the deceased clearly stated their objection to this before their demise. ${ }^{83}$ The right of access to medical records is frequently contradicted by the physician's obligation to maintain medical secrecy. In German jurisprudence, the term "breach of medical confidentiality" may refer to: a) an exemption of a physician, ${ }^{84}$ a nurse ${ }^{85}$ or other hospital staff to testify at trial

\footnotetext{
${ }^{74}$ OLG Munchen, 19.04.2001 - 1 U 6107/00, para 2-13 (facts); para. 25-26 (concerning damage to records).

${ }^{75}$ See e.g. OLG Köln, 12.11.1981: 7 U 96/81, para. 20-21; OLG Karlsruhe, 36.03.2007 - 2Ws $322 / 06$, para. 3 .

${ }^{76}$ See also comment, BVerfG, 16.09.1998 - 1 BvR 1130/98, para. 4.

${ }^{77} B G H, 06.12 .1988$ - VI ZR 76/88, para. 9.

${ }^{78} B G H, 06.12 .1988$ - VI ZR 76/88, para. 7-10.

${ }^{79} B G H, 02.10 .1984$ - VI ZR $311 / 82$ at p. 5.

${ }^{80}$ OLG Karlsruhe, 36.03.2007 - 2Ws 322/06, para. 3, 4-5.

${ }^{81}$ OLG Hamm, 23.02.2012 - 1 Vollz (Ws), 653/11, para. 13-21 and see other German court decisions cited.

${ }^{82} B G H, 06.12 .1988$ - VI ZR 76/88, para. 9-10.

${ }^{83} B G H, 31.05 .1983$ - VI ZR 259/81, para. 17-18; 20.

${ }^{84}$ See e.g. BVerWG, 25.09.1958 - BVerWG WDB 9/58 (A physician refused to testify in a suicide trial and was fined, appeal dismissed).

${ }^{85} B G H, 20.02 .1985$ - 2 StR $561 / 84$, para $7-11 ; 13-14$. (A nurse refused to testify concerning two burglars, one of whom was shot during an unsuccessful robbery of an electric shop. However, she was not allowed to conceal the facts beyond the treatment of the patient).
} 
concerning one's state of health, treatment and similar facts in both civil and criminal actions, which is quite far from being absolute, especially in the latter case; b) a breach of privacy by disclosing a patient's health data to third parties this may be any disclosure, from divulging the contents of a patients' list, ${ }^{86}$ to sharing one's medical records with non-medical hospital staff. ${ }^{87}$ Undoubtedly, disclosure of medical records may cause harm to the plaintiff, e.g. obtaining or extending a driving license, but it may pursue a legitimate aim. ${ }^{88}$ The demise of the individual, who is the subject of the requested medical records, does not waive the confidentiality of the records, but it may be overridden by a substantial legal interest, e.g. to define the cause of death and, if negligence is proved, to sue for damages. ${ }^{89}$ In fact, in some Continental Europe countries, such as France ${ }^{90}$ and Belgium $^{91}$, the disclosure of one's health data had been criminalised by penal code provisions from quite an early date. Medical secrecy was also touched upon by the European Court of Human Rights in the trial of $Z$ against Finland. ${ }^{92}$

\section{The Development of German Jurisprudence Regarding Access to Medical Records, its Boundaries and Limitations}

The right of access to medical records, being performed either for bringing a malpractice, personal injury or wrongful death suit against a physician or a hospital, or for private discovery, was introduced into German case law in the late 1970s, not much later than in England. Several decisions, where courts ruled that there must be a nearly unlimited exercise of the right of access to medical records, occurred in 1978-79. In the 1978 decision of a regional court in Weltzar, the facts were simple. The plaintiff and his spouse requested a hospital to provide health

\footnotetext{
${ }^{86}$ LG Koln 02.04.1959 - 34 Qs 76/59; NJW 1959, 1598, at 1598-99.

${ }^{87}$ LAG Niedersachsen, 15.09.1993; 5 Sa. 1772/92 (A patient's medical records were revealed to non-medical staff of a hospital, the plaintiff managed to recover $6000 \mathrm{DM}$ in damages.

${ }^{88}$ BVerWG, 08.05.1970 - BVerWG VII ER 207.69. In this case, the plaintiff, previously a psychiatric patient, failed to obtain a driver's license owing to the fact he had an acute psychosis while in Frankfurt in the mid-60s. His appeal failed.

${ }^{89}$ BGH, 31.05.1983 - VI ZR 259/81, para. 17 and 28

${ }^{90}$ Watelet et Dallet c. Min. Publ., Cour de Cass.; Dall. Per. 1886 I 347, at 347-348. In this case, two physicians were convicted for a breach of professional (medical) confidentiality by revealing the history of illness and cause of death of Jules Bastien-Lepage, a French painter. The story was published in a local paper, La Matin. The doctors were fined upon a criminal code provision and their appeal was unsuccessful. The Art. 378 of the French Criminal Code criminalised the divulgement any professional secret, be it a confessionary or a medical one. Concerning the early meaning of the statute, see Min. Publ. c. Berton, Trib. Corr. De la Seine, Mai 19, 1900, Dall. Per. 1901 II 81, p. 81-82 and note: the case was concerning a priest, but the note gives a comprehensive description of any divulgement of secrets, including medical ones. Concerning the medical secrets of personal records belonging to newborn children, see OLG Bayern, 07.02.1996 - 1 Z BR 72/95.

${ }^{91}$ Cass. 14 juin. 1965, Procureur General Pries La Cour de Bruxelles c. Dresse et Deflorenn, Pas. 1965. I 1102, 1103; on the criminalization of the breach of professional secrets (under Art. 478 of the Belgian Criminal Code), see older jurisprudence: Cass. 20 fevrier 1905, Procureur General a Bruxelles, a Charge d'Inconnus, Pas. 1905 I 141, 142-143; Albert Muller, Cass. 1 juillet 1912, Pas. 1912 I 367, 369.

${ }^{92} Z$ v Finland, [1997] 25 EHRR 371.
} 
records, while collecting evidence that the treatment that had been proscribed for their neonatal child, hadn't been performed at all. The hospital refused to furnish the records and the plaintiff took the matter to court. The court granted an order to allow the plaintiff access to the health records, finding that the couple's right to information derives from the contract of treatment. ${ }^{93}$ In a 1978 decision from Gottingen, the plaintiff was operated upon to remove his thyroid gland in 1975, but during the operation his vocal cords were severely injured. He subsequently commenced a negligence action and requested that his photocopied medical records and x-rays be examined by an appointed doctor. The defendants claimed that the medical records had been seized in the course of a preliminary investigation. The court expressed a dictum that not all information, but only treatment information should be supplied to the plaintiff, in order to avoid causing him psychological harm. The court, however, rejected the proposition that laymen are not entitled to see the documents, as the plaintiff could employ a skilled advisor to interpret them.

The seizure of documents was also found to be an unacceptable excuse, as the relevant record could also have been checked within the course of the investigation at the prosecutor's office. The court decided for the plaintiff, noting that there may be cases when the doctor may believe that some information may even cause the plaintiff to commit suicide if reviewed, but this was not the case. ${ }^{94}$ Surprisingly, in its 1982 decision, the Supreme Court found that the German legal and medical literature opposed the patient's right to insight, though the courts declined to follow the concept elaborated and discussed by the 1970 s authors. ${ }^{95}$ In a late 1970 s judgment from Limburg, a couple requested access to the hospital records of their neonatal child's treatment, but were denied. The court ruled that the defendant hospital's actions impaired the plaintiffs' right to self-determination; the contractual right to examine medical documents lies in the sphere of the patient's personal responsibility, and it is the patient's responsibility to contend with all the risks of disclosure. The court also augmented that the case before the tribunal did not come under the purview of "flattering consequences". Concerning the exceptions, the court noted that they may concern either the chances of recovery, or may derive from a special treatment contract provision, or may alternatively originate from a separate agreement. Therefore the court decided for the plaintiff and held that the defendant had no legitimate interest in obstructing the examination of the records. ${ }^{96}$ In a 1979 Bremen decision, the plaintiff sought access to records in order to file a medical malpractice suit, and the court affirmed his right to insight; concerning the "detrimental effects", the court determined that they were basically the "other side" of the "personlichkeitrecht", and there were no grounds for concealing the information, at least regarding the specific case. The court recognised that the inspection of hospital records is actually a form of

\footnotetext{
${ }^{93} A G$ Weltzar, 15.08.1978 - 3C 707/78, (para. 8-9; 15).

${ }^{94}$ LG Gottingen, 16.11.1978 - 2 O 152/78, para. 9-16.

${ }^{95}$ See BGH, 23.11.1982; VI ZR 222/79, para. 10; for an example, see Daniels (1976) at 348-349.

${ }^{96}$ LG Limburg, 17.01.1979 - 3 S 244/78, para. 7-8; 10; 13 (key points).
} 
"informational self-determination", in the same mode as informed consent to treatment. $^{97}$

The scope and limits of the right to access were firmly designed by two surprising 1980s judgments: a 1981 decision in Cologne, and the Supreme court's 1982 decision. In the first instance, the plaintiff was a woman who had been under the defendant's treatment repeatedly since 1969 . He had already removed her right breast in order to address carcinoma in 1975. In 1979 the plaintiff was diagnosed with liver cancer. The defendant repeatedly missed check-ups and the plaintiff blamed the defendant for failure to detect her cancer earlier. In order to prove this, she requested the medical history recorded in 1975-79, but was denied. She petitioned the court to either: a) grant her access to records, or b) take photocopies of all the records; c) allow her or her representative to inspect her health records. ${ }^{98}$ The defendant claimed there is no legal basis to request the production of the records. The court held that in any case where a patient has a firm legal interest, the access may be granted, and noted that indeed there may be some medical records that may not be shown to the plaintiff, but to another person "subject to secrecy" (i.e. another physician). ${ }^{99}$ The court firmly rejected the claim that laymen may find the information in medical records incomprehensible, stating that even if this were the case, a plaintiff may consult lawyers or other physicians to clarify complicated data. The court also firmly denied that insight into medical records may affect the adequate handling of the data by physicians. ${ }^{100}$ The court added that there may a claim of secrecy in certain situations, e.g. if third parties' data is involved, but this was not the case. Moreover, the defendant's fear that the plaintiff would use the records to consult with an unsuitable professional was ungrounded, as it is the plaintiff's right to decide whom to consult with. The court decided in favour of the plaintiff. ${ }^{101}$ Interestingly, in this ruling the Cologne court stringently opposed the position of the English court in the case of Davidson v. Lloyd Aircraft Services Ltd. In that case, the plaintiff, a liaison engineer, had contracted tropical malaria and a number of further health complications that caused him to be unable to work. The plaintiff attempted to file an action against his employer, an English aircraft company that had let him go to Zanzibar without proper vaccinations. ${ }^{102}$ There, the English court firmly denied the plaintiff's right to direct insight to the medical records, insisting, inter alia, that laymen are unable to understand them properly. However, this and the earlier 1970s judgments were overruled by the McIvor judgment in 1978. ${ }^{103}$

In the Supreme Court's 1982 judgment, the facts were somewhat similar. In 1976 the plaintiff underwent an operation on his cervical cord to prevent its further constriction and stop the progressing paralysis. After the operation he didn't feel

\footnotetext{
${ }^{97}$ OLG Bremen, 31.07.1979 - 1 U 47/79, para. 15-et seq.(key points). Concerning the rule of informed consent, the Court cited the leading case of the Federal Supreme Court: BGH, 16.01.1959 - VI ZR 179/57.

${ }^{98}$ OLG Koln, 12.11.1981, 7U 96/81, para. 1-8 (facts).

${ }^{99}$ OLG Koln, 12.11.1981, 7U 96/81, para 18; 20.

${ }^{100}$ OLG Koln, 12.11.1981, 7U 96/81, para. 24-25.

${ }^{101}$ OLG Koln, 12.11.1981, 7U 96/81, para. 27; 29-30.

${ }^{102}$ Davidson v Lloyd Aircraft Services Ltd., [1974] 1 W.L.R. 1042, 1043-1044.

${ }^{103}$ McIvor v Southern Health \& Social Service Board, [1978] 1 W.L.R. 757, 760-761.
} 
better, but instead the paralysis worsened. While preparing a negligence lawsuit he attempted to obtain his treatment records. The plaintiff employed a lawyer and a physician to assist him. The defendant claimed: 1) he would not let plaintiff's lawyer examine the health records; 2) it may affect property rights in the medical records; 3 ) the revelations may be detrimental to the patient. ${ }^{104}$ The court ruled that the plaintiff generally had a right to access deriving from the contract, but it was necessary to examine and determine its precise scope. ${ }^{105}$ The Supreme Court affirmed that the right to insight is contractual by nature, and originates from the patient's right to self-determination and dignity, as a patient is not a mere object of treatment, and has a number of basic rights concerning his treatment. ${ }^{106}$ In a similar manner to the Cologne tribunal in the decision described above, ${ }^{107}$ the court came to the following conclusions: 1) it is not true that all laymen (herein the patients) cannot comprehend medical information, and if this is the case, they may ask for professional advice; property rights or copyrights in the medical records do exist, but they may surrender to "personlichkeitrecht", the personal rights of the patient involved; 2) the "detrimental effect" (at least in cases akin to this one) may surrender to the right to self-determination despite the negative consequences that may occur if the patient examines the records (though, as the Limburg court denoted, the patient, by accessing records, takes all risk upon himself) 3) hence, the only known restriction is the "patient-physician privilege" which may be hardly applicable to most cases; 4) the court acknowledges that there may be communications between doctors concerning patients that may not be accessible or subject to revelation, as they may contain subjective language or alleged diagnoses - generally speaking, information not intended for patient insight. However, that is not the case in this instance and, in general, is neither frequently requested nor mentioned; Thus, the court ruled that the plaintiff may have a right to access his medical records, limited only to scientific findings. ${ }^{108}$

\section{Complications with Psychiatric Records}

There are some types of medical records that are deemed highly confidential by their nature, much more than ordinary health records. For instance, the US courts held that HIV-status records, ${ }^{109}$ donor lists ${ }^{110}$ and psychiatric records ${ }^{111}$ are highly confidential. German judges have confirmed the same position as well. ${ }^{112}$

\footnotetext{
${ }^{104} B G H, 23.11 .1982$; VI ZR 222/79, para. 1-5 (trial facts).

${ }^{105} B G H, 23.11 .1982$; VI ZR 222/79, para. 14-15.

${ }^{106} B G H, 23.11 .1982$; VI ZR 222/79, para. $15-16$.

${ }^{107}$ OLG Koln, 12.11.1981, 7U 96/81, para. 18-27.

${ }^{108} B G H, 23.11 .1982$; VI ZR 222/79, para. 17-27; 30.

${ }^{109}$ Doe v. Roe, 155 Misc. 2d 392, 397; 588 N.Y.S. 2d 236, 240 (1992).

${ }^{110}$ However, in cases where a person (plaintiff) was contracted with AIDS by blood transfusion, the identity of the blood donors and other personal data (e.g. addresses, basic medical records) may be disclosed upon a court order. See Tarrant County Hospitals v. District v. Hughes, 734 S.W.2d 675, 678-680 (Tex. App. - Fort Worth 1987); Boutte v. Blood Systems Ltd, 127 F.R.D. 122, 125-126 (1987); Stenger v. Lehigh Valley Hospital Center, 609 A.2d 796, 803 (1992). This position of several American courts is far from being omnipresently recognised.

${ }^{111}$ Indeed, in some American jurisdictions, psychiatric records were even bound to be disclosed upon a subpoena: In $\operatorname{Re} B, 394$ A. 2d 419, 425-426 (1978) [per curiam]. However this approach was
} 
In the Supreme Court's 1984 ruling, the plaintiff was treated at a closed psychiatric asylum in 1965. He believed that he was put there in the course of some criminal investigations, seemingly unknown to him previously. After nearly twenty years, he desired to check his medical records. By the time the trial commenced, the plaintiff's symptoms had already been gone for over a decade. The regional court permitted the access but the defendant appealed; affirming the right to access, the court held that insight may be limited, depending on the type of plaintiff's disease or his actual health condition. While the records the plaintiff had requested were psychiatric ones, that didn't mean they were explicitly exempt from review. The defendant didn't express any adequate objections, demonstrating simple unwillingness instead; upon the appellate court's assessment, it was determined that the revelation might not affect the plaintiff's health in any way; thus, the court reaffirmed the judgment, emphasizing that a physician's objections must be grounded and justified, and not on mere speculations, but on facts and conclusions. $^{113}$

The Supreme Court's judgment from 1988 also touched upon the problems of insight into psychiatric records based on the chances that the plaintiff's symptoms may reoccur. The plaintiff, a former psychiatric facility patient, requested the hospital to produce his medical records involving his treatment in 1976-1981, having had a brief insight of these records in the presence of a physician prior to the lawsuit. But after he was twice hospitalised in 1986 and 1987, his application was withdrawn, as the physicians determined that the insight might worsen his health condition. Therefore the plaintiff lodged his lawsuit. In this case, the plaintiff did not actually desire to examine regular treatment facts, such as the results of medical examinations, he was interested in what doctors thought of his condition. The court affirmed his actual right to inspection, but noted that the right may be considerably reduced to psychiatric data. The court ruled that disclosure of the requested information may cause the patient's mental condition to deteriorate or that the patient may mistakenly communicate the findings to other physicians who may treat or consult him. ${ }^{114}$ The court argued that a physician has a right to restrict the available records to those with 'therapeutic' aspects. At the same time, psychiatric records themselves are not strictly inaccessible. However, in case of subsisting hypochondria, the access to records may be restricted on the basis of this fact, meaning it may be disclosed to an appointed medical advisor, or a fellow physician, or not to be disclosed to the plaintiff in detail. In the abovementioned case, the court found that access to the requested information might cause the plaintiff paranoia. Finally, the court ruled to grant the plaintiff access to the records, but only in the presence of a treating physician, who would explain the information found in the records. ${ }^{115}$

not uniform. See Ceasar v. Mountanos, 564 F2d. 1064, 1068-1069 (1978). The state of Pennsylvania recognised the right to privacy in psychological test results in a child custody litigation, over the necessity to disclose them to other parties involved, see In Re T.R., 731 A.2d. 1276, 1280-1282 (1999).

${ }^{112} B G H, 06.12 .1988$ - VI ZR 76/88, para. 7.

${ }^{113} B G H, 02.10 .1984$ - VI ZR 311/82, originally reported at 5-8.

${ }^{114} B G H, 06.12 .1988$ - VI ZR 76/88, para. 3, 4-7 (facts).

${ }^{115} B G H, 06.12 .1988$ - VI ZR 76/88, para. 9-10. 
In a later judgment from Saarbrucken, the plaintiff desired to access his health records regarding previous psychiatric treatment. He desired not only ordinary records, but to obtain facts of "evaluative nature" and other details of his treatment, claiming these were required for his employment and for receiving insurance. This request was denied. Though the court confirmed his secondary contractual right in access, psychiatric records are quite restricted in their nature. Thus it is possible that in separate instances, the claimant, though not bearing an obligation to demonstrate a legal interest in purveying health records, may be requested to justify the reasons for disclosure. Taking into account that the plaintiff in this matter had already been employed and did not explain the reasons for his request for access at the trial (e.g. a need to commence a malpractice action or something similar), the court dismissed the appeal. ${ }^{116}$

Occasionally, the right to inspect medical records may be transferred to the heirs of the deceased person concerned. As I mentioned in my recent paper on data privacy and banking secrecy, several Continental Europe states, namely Germany, Austria, Switzerland and Liechtenstein have transferred the right to inspect a deceased person's banking records to all their heirs. ${ }^{117}$ The Supreme Court's 1983 decision cast a light on this complicated issue. The plaintiffs were the widow and daughter of a man who was unsuccessfully treated in the mid- to late 1970s, having suffered from appendicitis, inflammatory conditions of his lungs, pleura and an abdominal cavity outlet infection. The patient presumably died in late 1978 and the heirs, after having suspected malpractice, contacted a medicine negligence centre to determine the cause of death and, if malpractice was confirmed, to sue the hospital for damages. The surgeon of the negligence centre requested the medical records to make a verdict, but the hospital firmly refused to divulge the medical records. ${ }^{118}$ The court determined that the plaintiffs were not conventionally obliged to demonstrate a legal interest in insight, and that a patient's death shouldn't deprive them of such right. The court asserted that there are property rights within the right to inspect records, since the heirs had a well-understood legal interest in defining the cause of death, and if negligence was proved, to sue for damages, stating that the property rights of the deceased patient are transferred to his heirs with his presumed consent. The court added, however, that the "transfer" derives from secondary contractual rights, not in the sense of bequeathing ordinary property. ${ }^{119}$ The court also stated that the issue of medical confidentiality in this case should be properly clarified. In fact, as a general rule, medical confidentiality is bound to be breached without the implied or explicit consent of the patient, or in some exceptional circumstances. The court found that the heirs may have a right to access unless the deceased had, at some point, forbidden it, ${ }^{120}$ claiming that the contractual right to inspection may be somehow "transferrable", and the determination of the cause of death may be justifiable to "relational" access. In such cases the will of the deceased must be taken into

\footnotetext{
${ }^{116}$ LG Saarbrucken, 20.09.1995 - $16 \mathrm{~S}$ 1/93, see key points at para. 7-8.

${ }^{117}$ Lytvynenko (2019b) at 311.

${ }^{118} B G H, 31.05 .1983$ - VI ZR 259/81, para. 2-6 (facts).

${ }^{119} B G H, 31.05 .1983$ - VI ZR 259/81, para. 9; 12.

${ }^{120} B G H, 31.05 .1983$ - VI ZR 259/81, para. 13-14; 17;18.
} 
account, but not absolutely; according to the court, medical secrecy, as such, is not an acceptable justification for denying access to medical data. Thus, the court found that a right to insight of close relatives as heirs may allow the breach of medical confidentiality if properly justified. Based on this, the court found in favour of the plaintiff and the case was remanded. ${ }^{121}$ In a later judgment from Essen, the relatives of a deceased patient were granted the right to access to his medical records, hoping to discover the cause of his demise (and, if negligence was confirmed, to file a wrongful death suit), based upon a contractual right to insight; as another aspect of their action, nearly all medical records were unreadable, and the court affirmed their right to inspect the entries in a conceivable form. $^{122}$

\section{Summary and Hints for the European Court of Human Rights}

In both Anglo-Saxon and Continental legal systems, the courts recognise that a patient has a right to inspect their medical records either in the course of prelitigation (or after commencing a malpractice suit), or for their own private purposes. What general rules may be derived from the German jurisprudence in trials akin to Gaskin, Martin, Odievre or Godelli? Following are some conjectural ideas:

a) The property rights in the hospital records belong to the physician or hospital, but these rights are qualified to the patient's rights, ${ }^{123}$ and the German jurisprudence held that the patient also possesses property rights in their medical records; ${ }^{124}$

b) In non-psychiatric cases, the detrimental effect of examining medical records is considerably minimalised, though not completely void. At the same time, the right to self-determination in its informational component stringently means that the plaintiff should be prepared to behold the facts at their own risk; ${ }^{125}$

c) It is incorrect to assume that laymen are not intelligent enough to comprehend at least a part of their medical records. ${ }^{126}$ At the same time, they are free to choose any advisors they might necessitate, and it is unacceptable for a physician or hospital to withhold the production of files based upon the argument that the records may be transferred to an incompetent or in some way unreliable person; this is with the patient's autonomous discretion;

d) The physician and the hospital cannot object to the production of medical records merely by their own desire. Any objection must be justified and the defendant is expected to be ready to prove their objection at trial. ${ }^{127}$

\footnotetext{
${ }^{121} B G H, 31.05 .1983$ - VI ZR 259/81, para. 19-20; 25; 28; 30.

${ }^{122}$ A G Essen, 21.04.1997 - 12 C13/97, para. 5-6.

${ }^{123} B G H, 23.11 .1982$; VI ZR 222/79, para. 17.

${ }^{124} B G H, 31.05 .1983$ - VI ZR 259/81, para. 9.

${ }^{125}$ LG Limburg, 17.01.1979 - 3 S 244/78, para. 8-9.

${ }^{126}$ OLG Koln, 12.11.1981, 7U 96/81, para. 24.

${ }^{127} B G H, 06.12 .1988$ - VI ZR 76/88, para. 7-10.
} 
Such objections, as the inability of the plaintiff to conceive the writings, are not accepted by the courts: ${ }^{128}$

e) Psychiatric records, being highly confidential, are restricted in access, but are not exempt from the right to inspection with limitations deriving from specific circumstances.

f) The contract-originating right to access may be transferred to a decedent's heirs in case they display a legal interest in insight, and the deceased person hadn't objected, at some point, to disclosing this information to their closest relatives. ${ }^{129}$

g) Plaintiffs who are maintained in psychiatric institutions or penitentiaries must not be deprived of the right to insight, but the fact of their confinement may impose additional rules of access, or limited disclosure of facts, or an inspection of the records by specially appointed professionals. ${ }^{130}$

h) Concerning trials commenced to grant access to medical records in adoption cases, the European Court strives to strike a balance in two directions: 1) between the privacy rights of the offspring and the birth parent; 2) the legislative balance establishing at least some remedy, such as access to anonymised records. ${ }^{131}$

The value of the said records is, however, doubtful. At the same time, I believe that the given "tests" must be augmented. France, Italy and other states recognizing a "right to anonymous birth" possess at least some jurisprudence upon which exceptions are frequently laid down. As the case law in "civil law" legal systems primarily derives from various statutes (laws, decrees and civil or other code provisions), bare code provisions without jurisprudence will not give an explicit landscape of what is the law concerning a particular subject.

\section{Conclusion}

In conclusion, it seems that the progressive development of law lies in jurisprudence, or case law. The principle of precedence is both successfully disposed in both Commonwealth and Continental legal systems. The jurisprudence of the ECHR is still relatively young and developing. For these reasons, the jurisprudence of various states is a perfect source for elaborate general rules in complicated actions that are brought before the European Court. Therefore, the given paper was devoted to a review of German jurisprudence on the subject of access to medical records. The author shares a thought that the analysis of national jurisprudence is quite sufficient to develop general rules of adjudicating cases that are brought before international human rights courts.

\footnotetext{
${ }^{128}$ LG Gottingen, 16.11.1978 - 2 O 152/78, para. 15; OLG Koln, 12.11.1981, 7U 96/81, para. 24.

${ }^{129} B G H, 31.05 .1983$ - VI ZR 259/81, para. 18; 20.

${ }^{130}$ See OLG Karlsruhe, 26.03.2007 - 2 Ws 322/06, para. 4; 11-et seq.

${ }^{131}$ Godelli v Italy, [2012] ECHR 374, para. 50; 54-56.
} 


\section{References}

Bulletin officiel du Ministère de l'intérieur, 1904 I 273 at gallica.bnf.fr/ark:/12148/bpt6k 55339232/f13.image

Crane, A.E. (1986) Annual Survey of American Law, at 645.

Daniels, J. (1976). 'Die Ansprüche des Patienten hinsichtlich der Krankenunterlagen des Arztes', in NJW 1976:345-349.

Demont, L. (2000). 'Secret medical et instance judiciare' 'Secret medical et instance judiciare', Rev. Juridique de l'Quest ( $N^{\circ}$ Spécial 2000 75-100.

Deutsch, E. (1992). 'Das Persönlichkeitsrecht des Patienten' in Archiv für die civilistische Praxis, 192(3):161-180.

Dworkin, G. (1979). 'Access to Medical Records - Discovery, Confidentiality and Privacy' in Modern Law Review 42(1):88-91.

Feenan, D. (1996). 'Common Law Access to Medical Records' in Modern Law Review 59(1): 101-110.

Harpst, R.J. (1962). 'Ownership of X-Rays' in Clev.-Marshall L. Rev. 11(2): 272-278.

Lytvynenko, A.A. (2019a). 'Common Law Right to Access to Medical Records: The Commonwealth and European Court of Human Rights Practice', $7^{\text {th }}$ International Conference of PhD Students And Young Researchers: "Law 2.0: New Methods, New Laws", Vilnius, Lithuania.

Lytvynenko, A.A. (2019b). 'Data Privacy and Banking Secrecy: Topical issues in Commonwealth, Continental Europe and International Jurisprudence', in Athens Journal of Law 5(3):303-322, Doi=10.30958/aj1.5-3-5.

Passion, L. (1983). 'Législation et prophylaxie de l'abandon à Paris au début du XXème siècle' in Histoire, économie \& société 2(3):475-496.

Wischnath, M. (1998). 'Einführung zu den Bewertungs- und Erschließungsempfehlungen für Krankenakten' in Der Archivar, Jg. 51 (2): 233-244.

\section{Cases}

\section{European Court of Human Rights}

B.F.B. Villa-Nova v Portugal, [2015] ECHR 1049

Gaskin v United Kindgom (1989) 12 EHRR 36

Godelli v Italy, [2012] ECHR 347

GSB v Switzerland, [2015] ECHR 1122

Khehili v Switzerland, [2011] ECHR 195

Leander $v$ Sweden [1987] 9 EHRR. 433

MG v United Kindgom, App. 39393/98, judgment of 29 Sept. 2002

Odievre v France, [2003] F.C.R. 621

Roche v United Kingdom [2005] ECHR 956

Rotaru v Romania, [2000] ECHR 92

$S$ \& Marper. United Kindgom, [2008] ECHR 1581

Szulc. Poland, [2013] 57 EHRR. 5

Z v Finland, [1997] 25 EHRR 371 


\section{$\underline{\text { Australia }}$}

Breen v. Williams, [1996] H.C. 78

\section{$\underline{\text { Austria }}$}

OGH 23.5.1984, 1 Ob 550/84

\section{$\underline{\text { Belgium }}$}

Cass. 1 juillet 1912, Albert Muller, Pas. 1912 I 367

Cass. 14 juin. 1965, Procureur General Pries La Cour de Bruxelles c. Dresse et Deflorenn, Pas. 1965. I 1102

Cass. 20 fevrier 1905, Procureur General a Bruxelles, a Charge d'Inconnus, Pas. 1905 I 141

\section{Canada}

Lamothe v. Mokleby \& Erle Holdings Co., 106 D.L.R. (3d) 233 (1979)

McInerney v. Macdonald, [1992] 2 S.C.R. 138

Re Mitchel \& St. Michael's Hospital, 112 D.L.R. (3d) 360 (1980)

\section{Federal Republic of Germany}

AG Essen, 21.04.1997 - 12 C13/97

AG Neunkirchen, 28.10.1991, 5 C 648/91

AG Weltzar, 15.08.1978 - 3C 707/78

$B G H, 11.04 .1956$ - VI ZR 20/55

$B G H, 16.01 .1959$, VI ZR 179/57

$B G H, 23.11 .1982$; VI ZR 222/79

$B G H, 31.05 .1983$ - VI ZR 259/81

$B G H, 02.10 .1984$ - VI ZR 311/82

$B G H, 20.02 .1985$ - 2 StR 561/84

$B G H, 06.12 .1988$ - VI ZR 76/88

BVerfG, 16.09.1998 - 1 BvR 1130/98

$B$ VerWG, 25.09.1958 - BVerWG WDB 9/58

$B$ VerWG, 08.05.1970 - BVerWG VII ER 207.69

LAG Niedersachsen, 15.09.1993; 5 Sa. 1772/92

LG Gottingen, 16.11.1978 - 2 O 152/78

LG Koln 02.04.1959 - 34 Qs 76/59; NJW 1959, 1598

LG Limburg, 17.01.1979 - 3 S 244/78

LG Saarbrucken, 20.09.1995 - 16 S 1/93

OLG Bayern, 07.02.1996 - 1 Z BR 72/95

OLG Bremen, 31.07.1979 - 1 U 47/79

OLG Hamm, 23.02.2012 - 1 Vollz (Ws), 653/11

OLG Karlsruhe, 36.03.2007 - 2Ws 322/06

OLG Köln, 12.11.1981, 7U 96/81

OLG Munchen, 19.04.2001 - 1 U 6107/00 


\section{$\underline{\text { France }}$}

Mallet, 16 Sept. 1843, Cour de Cass.; Ch. Crim., Sirey 1843, I 915

Min. Publ. c. Berton, Mai 19, 1900, Trib. Corr. De la Seine, Dall. Per. 1901 II 81

Romieux c. Min. Publ, 1 Juin 1844, Cour de Cass.; Ch. Crim., Sirey 1844 I 669

Watelet et Dallet c. Min. Publ., Cour de Cass.; Dall. Per. 1886, I 347

\section{United Kingdom}

England

Church of Scientology v DHSS, [1979] 1 W.L.R. 723.

$D v$ NSPCC, [1978] A.C. 171.

Davidson v Lloyd Aircraft Services Ltd., [1974] 1 W.L.R. 1042.

Deistung v South West Metropolitan Regional Hospital Board, [1974] 1 W.L.R. 213.

Dunning v United Liverpool Hospitals' Board of Governors, [1973] 1 W.L.R. 586.

In Re D (Infants), [1970] 1 W.L.R. 599.

McIvor v Southern Health \& Social Service Board, [1978] 1 W.L.R. 757.

R. v Mid Glamorgan Family Health Services Authority \& Another/Ex Parte Martin, [1995] 1 W.L.R. 110.

Scotland

Boyle v Glasgow Royal Infirmary and Associated Hospitals, 1969 SC 72; 1969 S.L.T. 137.

\section{$\underline{\text { United States of America }}$}

Boutte v. Blood Systems Ltd, 127 F.R.D. 122 (1987).

Ceasar v. Mountanos, 564 F2d. 1064 (1978).

Cannell v. Medical and Surgical Clinic, 315 N.E.2d 278 (1974).

Clay v. Little Co. of Mary Hospital, 277 Ill.App.3d 175; 213 Ill.Dec. 866; 660 N.E.2d 123 (1995).

Doe v. Roe, 155 Misc. 2d 392; 588 N.Y.S. 2d 236 (1992).

Hoyt v. Cornwall Hospital, 169 Misc. 361 (N.Y. 1940).

Humphers v. First Interstate Bank, 298 Or. 706; 696 P. 527 (Or. 1985).

In Re B., 394 A. 2d 419 (1978).

In Re June 1979 Allegheny County Grand Jury Investigation, 415 A.2d 73 (1979-80).

In Re T.R., 731 A.2d. 1276 (1999).

In re Weiss, 147 N.Y.S 2d. 455 (1955).

Kirsch v. Parker, 383 So. 2 d 384 (La. 1980).

Massey v. Parker, 369 So. 2d 1310 (La. 1979).

Rabens v. Jackson Park Hospital Foundation, 40 Ill.App.3d 113; 351 N.E.2d 276 (1976).

Stenger v. Lehigh Valley Hospital Center, 609 A.2d 796 (1992).

Tarrant County Hospitals v. District v. Hughes, 734 S.W.2d 675 (Tex. App. - Fort Worth 1987). 